\title{
KEMITRAAN ANTARA SEKOLAH, ORANG TUA, DAN LEMBAGA-LEMBAGA SOSIAL KEMASYARAKATAN DI MADRASAH ALIYAH NEGERI SALATIGA
}

\author{
Fatchurrohman \\ Institut Agama Islam Negeri Salatiga \\ Jl. Lingkar Salatiga KM 2 Pulutan, Kota Salatiga, Jawa Tengah, 50721 \\ E-mail: artur.neno@yahoo.co.id
}

\begin{tabular}{c|c|c}
\hline Received: & Revised: & Approved: \\
$30 / 05 / 2018$ & $15 / 07 / 2018$ & $27 / 08 / 2018$ \\
\hline
\end{tabular}

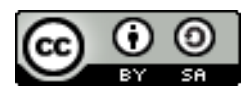

Kemitraan Antara Sekolah, Orang Tua, dan Lembaga-Lembaga Sosial Kemasyarakatan di Madrasah Aliyah Negeri Salatiga Licensed Under a Creative Commons Attribution-ShareAlike 4.0 International License

\begin{abstract}
This study was aimed at determining the background of thought that underlies the education partnership in MAN Salatiga, the implementation of educational partnerships among the schools, parents, and social institutions in MAN Salatiga, and the impact of the partnerships among the schools, parents, and social institutions in the city Salatiga to improve the quality of schools, school culture, graduates, and parents. This type of research was a qualitative interpretive approach, which took place in MAN Salatiga, and community social institutions (Indonesian Red Cross, Indonesian National Sports Committee, Asmoro Budoyo Circle of Friends, Prana Shakti Jaka Tingkir Respiratory Self Defense College) in the city of Salatiga. Data were collected through interviews, observation, and document study. The data were then analyzed by following the stages developed by Yin and Stake, namely the stage of holistic analysis, embedded analysis, analysis of themes, within case analysis, and cross case analysis. The results of the study show that MAN Salatiga sees the need to utilize various resources in the community to overcome various limitations
\end{abstract}


in the implementation of education in order to meet the demands of the community. The development of educational partnerships in MAN Salatiga is supported by social capital which is influenced by the type of school, initiative and interest, parental circumstances, school policy and political participation. Education partnerships in MAN Salatiga affect the quality of the schools, graduates, and parents.

Keywords: Partnership, School, and Community Social Institutions.

\begin{abstract}
Abstrak
Penelitian ini bertujuan untuk mengetahui latar belakang pemikiran yang mendasari kemitraan pendidikan di MAN Salatiga, pelaksanaan kemitraan pendidikan antara sekolah, orang tua, dan institusi sosial kemasyarakatan di MAN Salatiga, dan dampak kemitraan antara sekolah, orang tua, dan lembaga-lembaga sosial kemasyarakatan di kota Salatiga terhadap perbaikan kualitas sekolah, budaya sekolah, lulusannya, dan orang tua. Jenis penelitian ini adalah kualitatif dengan pendekatan interpretatif, yang mengambil lokasi di MAN Salatiga, dan lembaga sosial kemasyarakatan (Palang Merah Indonesia, Komite Olahraga Nasional Indonesia, Paguyuban Asmoro Budoyo, Perguruan Beladiri Pernafasan Prana Shakti Jaka Tingkir) di kota Salatiga. Pengambilan data dilakukan melalui wawancara, observasi, dan studi dokumen. Data yang terkumpul dianalisis dengan mengikuti tahapan yang dikembangkan oleh Yin and Stake, yaitu tahap holistic analysis, embedded analysis, analysis of theme, within case analysis, dan cross case analysis. Berdasarkan pembahasan dapat disimpulkan, bahwa MAN Salatiga memandang perlunya meman-faatkan berbagai sumber daya dalam masyarakat untuk mengatasi berbagai keterbatasan penyelenggaraan pendidikan dalam rangka memenuhi tuntutan kebutuhan masyarakat. Pengembangan kemitraan pendidikan di MAN Salatiga didukung oleh modal sosial yang dipengaruhi oleh jenis sekolah, inisiatif dan interest, keadaan orang tua, kebijakan sekolah dan partisipasi politik. Kemitraan pendidikan di MAN Salatiga mempengaruhi mutu sekolah, lulusan, dan orang tua.
\end{abstract}

Kata Kunci : Kemitraan, Sekolah, dan Lembaga Sosial Kemasyarakatan.

\title{
A. Pendahuluan
}

Salah satu masalah yang dihadapi bangsa Indonesia adalah rendahnya mutu pendidikan, khususnya jenjang pendidikan dasar dan menengah. Berbagai usaha telah dilakukan, namun belum 
berhasil meningkatkan mutu pendidikan nasional. Berbagai análisis, menemukan tiga faktor penyebab mutu pendidikan di Indonesia tidak merata, yaitu kebijakan pendidikan nasional yang menggunakan pendekatan education production function, pendidikan nasional yang birokratik sentralistik, dan minimnya keterlibatan stakeholder di sekolah. ${ }^{1}$

Salah satu upaya yang dapat dilakukan untuk meningkatkan mutu pendidikan adalah penguatan kemitraan antara sekolah, orang tua, dan institusi kemasyarakatan terkait. Menurut Buchori “....orang tua dan masyarakat merupakan stakeholder yang selama ini diabaikan dalam pengelolaan pendidikan...". Sedangkan menurut Tilaar mengungkapkan bahwa salah satu kenyataan pendidikan masa orde baru adalah terpisahnya pendidikan dari masyarakat, akibatnya pendidikan terpisah dari kebutuhan masyarakat, dari dunia industri, dan dunia kerja. Gerakan desentralisasi pendidikan dalam UU No 22 Tahun 1999 berarti mengikutsertakan masyarakat dalam menentukan akuntabilitas pendidikan. ${ }^{2}$ Menurut Scott (dalam Jalal dan Supriyadi, 2001, pp.11,160), pelibatan guru, orang tua, dan masyarakat dalam pendidikan mampu meningkatkan rasa kepemilikan mereka terhadap sekolah, penggunaan sumber daya pendidikan lebih baik, kontrol kepala sekolah lebih besar, dan beban sekolah menjadi lebih ringan sehingga hasilnya lebih baik. ${ }^{3}$

Penja linan hubungan antara sekolah (MAN Salatiga), orang tua, dan lembaga sosial kemasyarakatan hingga kini belum sesuai dengan cita idal. Sebagian besar orang tua masih memiliki pemahaman yang keliru ketika memasukkan anak mereka ke MAN Salatiga. Mereka cenderung melepaskan diri dari tanggung jawab dan menyerahkan sepenuhnya tanggung jawab pendidikan anak kepada sekolah. Dalam menyelesaikan masalah anak, para pengelola MAN Salatiga lebih mengoptimalkan fungsi tenaga konseling di sekolah. Orang tua juga masih sulit dilibatkan dalam urusan pendidikan di sekolah.

1 Depdiknas, Manajemen peningkatan mutu berbasis sekolah: Konsep dan pelaksanaan (Jakarta: Depdiknas Direktorat SLP, 2002), 1.

2 Tilaar, H.A.R., Paradigma baru pendidikan nasional (Jakarta: Rineka Cipta, 2004), 58.

${ }^{3}$ Fasli Jalal dan Dedi Supriyadi (Ed), Reformasi Pendidikan Dalam Konteks Otonomi Daerah (Yogyakarta: Adicita, 2001), 111 dan 106. 
kajian ini fokus pada tiga hal, Pertama, apa orientasi pengembangan kemitraan pendidikan di MAN kota Salatiga, kedua, bagaimana pelaksanaan kemitraan pendidikan di MAN kota Salatiga, ketiga, apa dampak perubahan yang terjadi dengan adanya kemitraan pendidikan pada perbaikan kualitas dan budaya sekolah, lulusan, dan bagi orang tua setelah dikembangkannya kemitraan pendidikan di sekolah?

\section{B. Metode Penelitian}

Kajian ini merupakan hasil penelitian kualitatif case study kolektif, dengan pendekatan interpretif, yang dilakukan dengan memberikan interpretasi atas fakta melalui uraian yang mendalam dan disesuaikan maksud pelaku kegiatan. Penelitian ini berlokasi di MAN Kota Salatiga Jawa Tengah. Penelitian dilaksanakan pada bulan Juni-Agustus 2016.

Subjek dalam penelitian ini adalah kepala sekolah, wakil kepala sekolah bidang kerja sama, bidang kesiswaan, dan bidang kurikulum, petugas bimbingan dan konseling, ketua lembaga/organisasi sosial kemasyarakatan, kasi kurikulum disdikpora kota Salatiga, kabid dikmen disdikpora Kota Salatiga, dan orang tua peserta didik. Objek kajian yang ditekuni dalam penelitian ini adalah kemitraan antara sekolah, orang tua, dan lembaga sosial kemasyarakatan.

Teknik pengumpulan data dilakukan melalui wawancara, observasi, dan studi dokumentasi. Instrumen yang digunakan dalam penelitian ini meliputi pedoman wawancara, pedoman observasi, dan pedoman studi dokumentasi. Pemeriksaan keabsahan data penelitian dilakukan melalui triangulasi sumber dan metode, member checks, uraian rinci, dan konfirmasi.

Data yang terkumpul dianalisis dengan mengikuti tahapan yang dikembangkan oleh Yin dan Stake (yaitu melalui tahap holistic analysis, embedded analysis, analysis of theme, within case analysis, dan cross case analysis. ${ }^{4}$ Dalam kajian teori ini, diuraikan tentang : 1) Teori Modal Sosial, Jaringan, Pertukaran; 2) Sekolah, orang tua, dan masyarakat; 3) Kemitraan antara sekolah, orang tua, dan masyarakat.

${ }^{4}$ Creswell, J.W, Qualitative inquiry \& research design: Choosing among five approaches (California: Sage Publications, Inc, 2007), 75. 


\section{Modal, Jaringan, dan pertukaran sosial}

Modal sosial merupakan seperangkat sumber daya yang melekat pada hubungan keluarga dan dalam organisasi sosial kemasyarakatan, yang bermanfaat bagi perkembangan kognitif, afektif, dan sosial individu. Sumber-sumber daya tersebut berbeda bagi orang yang berlainan dan dapat memberikan manfaat bagi anak dan remaja dalam perkembangan mereka. ${ }^{5}$

Sosial capital adalah "...resources embedded in a social structure which are accessed and or mobilized in purposive actions'..." Fukuyama mendefinisikan, modal sosial merupakan serangkaian nilai atau norma informal yang dimiliki bersama di antara para anggota kelompok yang memungkinkan terjalinnya kerja sama diantara mereka. Menurut Cox, modal sosial adalah serangkaian proses hubungan antar manusia yang didukung oleh jaringan, norma, dan kepercayaan sosial yang memungkinkan terjadinya kerja sama secara efektif dan efisien untuk memperoleh keuntungan bersama.

Cohen mendefinisikan modal sosial sebagai setiap hubungan yang terjadi dan diikat oleh suatu trust, saling pengertian (mutual understanding), dan nilai bersama (shared value) yang mengikat anggota kelompok untuk melakukan kegiatan bersama agar tercapai tujuan secara efektif dan efisien.

Menurut teori jaringan kebudayaan dan sosialisasi antara invidu atau kelompok individu akan membentuk norma dan nilai, di mana pada tahap selanjutnya setiap individu yang menjadi anggotanya terinternalisasi oleh norma dan nilai tersebut. Internalisasi nilai-nilai tersebut selanjutnya akan mempengaruhi kuat lemahnya ikatan antar individu dalam kelompok.

Menurut Mizruci, terjadinya interaksi tersebut dipengaruhi oleh kuat atau lemahnya suatu relasi sosial antar individu dengan individu lainya. Interaksi akan lebih sering dilakukan oleh individu dengan individu lain karena adanya kesamaan nilai, gagasan bersama, dan interest, sedangkan antara individu yang tidak memiliki kesamaan nilai, gagasan bersama, dan interest frekwensi interaksinya

${ }^{5}$ Kusumastuti, Ayu, "Modal Sosial dan Mekanisme Adaptasi Masyarakat Pedesaan dalam Pengelolaan dan Pembangunan Insfrastruktur.," MASYARAKAT: Jurnal Sosiologi 20, no. 1 (2015): 81-97. 
lebih rendah. Dengan demikian, muncullah kohesi diantara sesama kelompok sosial tertentu yang memiliki kesamaan nilai dan norma.

Granovetter membedakan adanya ikatan kuat dan ikatan lemah dalam relasi antar individu. Ikatan kuat misalnya terjadi pada ikatan antara individu dengan teman-teman dekat mereka, dan ikatan lemah misalnya ikatan yang terjadi antara individu dengan kenalan barunya. Sedangkan Fennema, M and Tillie, J mengatakan bahwa perbedaan kuat lemahnya ikatan tidak didasarkan pada kemiripan sosial atau individu, namun didasarkan pada karakteristik ikatan yang menghubungkannya, yaitu frekwensi dan kedekatan .

Frekwensi adalah kekuatan ikatan yang didasarkan pada jumlah interaksi individu dalam jaringan, sementara itu kuatnya ikatan karena kadekatan adalah bahwa jika orang kunci dapat dengan cepat berinteraksi dengan seluruh yang lainnya. Pool and Kochen menyebut frekwensi terkait dengan banyaknya perjumpaan yang dilakukan secara teratur dengan teman koleganya, sedangkan kedekatan terkait dengan fleksibelitas seseorang dengan orang lain. Dia membedakan antara pekerja pekerja kerah biru dan pekerja profesional. Pekerja kerah biru cenderung sedikit bekerja namun lebih banyak kontak dengan koleganya, sementara itu pekerja profesional cenderung mengutamakan tugas pokoknya dari pada kontak dengan yang lain.

Dalam teori pertukaran, seorang individu atau kelompok individu dapat mempertukarkan pekerjaan atau pelayanan dengan orang lain dalam rangka memperoleh keuntungan atau kemanfaatan lain yang setimpal. Masing-masing mendapat timbal balik keuntungan atas peran yang dipertukarkan. Dalam pandangan Homans, individu melakukan pertukaran peran dalam rangka efisiensi, yaitu memperkecil biaya dan memperbesar keuntungan atau kemanfaatan. Teori pertukaran dipelopori oleh Homans, teori ini bertumpu pada asumsi bahwa orang terlibat dalam perilakunya dalam rangka untuk memperoleh ganjaran dan menghindari hukuman.

\section{Orientasi Pemikiran Kemitraan Pendidikan}

Kemitraan pendidikan yang dikembangkan di kota Salatiga didasarkan pada orientasi pemikiran bahwa pendidikan yang 
bermutu merupakan tanggung jawab bersama antara sekolah, orang tua dan masyarakat dalam rangka memenuhi kebutuhan masyarakat. Sekolah adalah bagian dari institusi sosial yang berusaha memberikan pengaruh positif kepada anak namun memiliki banyak keterbatasan. Sementara itu, masyarakat memiliki banyak sumber belajar yang dapat manfaatkan melalui sekolah untuk mengatasi keterbatasan tersebut melalui outdoor learning.

Menurut Abdullah Idi, masing-masing komponen pendidikan harus saling berhubungan satu sama lainnya secara efisien dan produktif. Dalam masyarakat modern, sekolah lebih dominan melaksanakan fungsi utama karena terbatasnya interaksi anak dengan orang tua, sementara itu dalam masyarakat pedesaan, keluarga banyak menjalankan fungsi pendidikan karena terbatasnya akses pendidikan formal. ${ }^{6}$

Menurut Coleman, guru dapat menggunakan berbagai sumber belajar di masyarakat dengan memanfaatkan jaringan sosial siswa dan keluarga, seperti keluarga besar, tetangga, anggota masyarakat, maupun kelompok masyarakat. Sumber belajar di masyarakat yang telah dimanfaatkan sekolah adalah pasar, tokoh masyarakat, pakar, taman kota, institusi pemerintah, institusi sosial kemasyarakatan, institusi keagamaan, dan museum. ${ }^{7}$ Menurut Drago \& Severson, agar guru mampu mengembangkan prestasi anak didik secara optimal, sekolah perlu memiliki kapasitas dalam school organizational capacity, instructional capacity, developmental capacity. ${ }^{8}$

Pendidikan diselenggarakan dalam rangka memenuhi kebutuhan masyarakat. Menurut Durkheimian, pendidikan tidak bisa dipisahkan dari masyarakatnya. Masyarakat dan pendidikan saling berinteraksi dan saling memberi pengaruh, pendidikan selalu berkait erat dengan institusi sosial lainnya. Dalam pandangan kaum kapitalis, sekolah harus mampu meyakinkan kepada masyarakat bahwa sekolah menyediakan banyak pilihan tenaga kerja yang dibutuhkan masyarakat industri. Menurut Durkheimian, masyarakat

6 Abdullah Idi, Sosiologi Pendidikan: Individu, Masyarakat, dan Pendidikan (Jakarta: Raja Grafindo, 2013), 169.

7 Coleman, J.S, Dasar-dasar teori sosial (Terjemahan Imam Muttaqien, Derta Sri Widowatie, SiwiPurwandari) (Bandung: Nusa Media, 2009), 39.

8 Abdullah Idi, Sosiologi Pendidikan: Individu, Masyarakat, dan Pendidikan, 171. 
dan institusi yang ada di dalamnya seperti pendidikan, kesehatan, agama, dan lainnya merupakan komponen-komponen yang saling bergantung. Sekolah adalah bagian dari komponen sosial harus mengaitkan diri dengan komponen lain agar mampu berkontribusi dalam menciptakan harmoni sosial. ${ }^{9}$

\section{E. Implementasi Kemitraan pendidikan \\ 1. Komunikasi}

Sekolah mengadakan pertemuan dengan orang tua pada awal tahun ajaran baru, ketika penerimaan rapor, dan pelepasan lulusan. Orang tua siswa tingkat akhir diundang ke sekolah untuk sosialisasi Ujian Nasional. Pada pertemuan awal tahun ajaran, komite sekolah berperan sebagi mediator antara sekolah dan orang tua. Orang tua juga diundang ke sekolah secara perorangan, jika ada masalah terkait dengan anak mereka. Khusus orang tua siswa kelas unggulan mengadakan pertemuan setiap tiga bulan sekali. Hasil pertemuan ditindaklanjuti sesuai dengan kesepakatan, biasanya diserahkan kepada sekolah, dan jika diperlukan bisa melibatkan orang tua. Program kegiatan sekolah dan berbagai kebijakan lainnya disampaikan pada waktu pertemuan dengan orang tua di awal tahun ajaran baru dan pada waktu penerimaan rapor. Selain itu, informasi mengenai kegiatan sekolah yang insidentil disampaikan melalui surat, telephone, dan web sekolah.

Menurut Olsen \& Fuller, banyak media yang dapat digunakan untuk mengkomunikasikan hasil kerja siswa, kegiatan siswa, atau keadaan siswa di sekolah kepada orang tua, misalnya folders, journals, card report, narrative report ataupun newsletter. Media komunikasi yang digunakan di kota Salatiga adalah telephone, majalah, dan buku rapor. Berbagai media lain belum dimanfaatkan sekolah karena beban kerja guru yang berat dan cara pandang guru yang pesimis terhadap para orang tua siswa. ${ }^{10}$

Beban guru adalah memikirkan bagaimana mengajar di kelas yang baik, mendongkrak nilai siswa dan menyelesaikan persoalan siswa sendiri atau dengan bantuan guru BK di sekolah. Para guru

${ }^{9}$ Zainuddin Maliki, Sosiologi Pendidikan (Yogyakarta: Gadjah Mada University Press, 2010), 89-166.

${ }^{10}$ Olsen dan Fuller, M.O., Home and school relation (New Jersey: Pearson, 2012), 121. 
memberikan laporan performa anak didik setiap semester sekali, karena dipandang simpel dan tidak merepotkan kerja guru. Di luar jam kerja para guru masih harus melakukan aktivitas keluarga dan sosial.

Guru memandang bahwa seandainya mengembangkan komunikasi berkala dengan orang tua, harian, mingguan atau dua mingguan tidak akan berdampak bagi performa anak. Para guru menganggap bahwa orang tua tidak memiliki kesempatan untuk mencermati media komunikasi harian atau mingguan. Orang tua harus bekerja penuh waktu untuk memenuhi kebutuhan hidup, profesi orang tua siswa MAN sebanyak $41.76 \%$ berprofesi sebagai petani. Profesi tersebut membuat para orang tua lebih memikirkan pekerjaannya dari pada pendidikan anaknya. Komunikasi sekolah dan orang tua ini sangat diperlukan dalam rangka membangun kepercayaan (trust) antar satu dan lainnya. Menurut Hauberer, hubungan saling percaya antara individu akan melahirkan harapan di satu pihak dan kewajiban di pihak lainnya. ${ }^{11}$

Antara sekolah dan orang orang juga terdapat relasi kewenangan, di mana sekolah mendapat kewenangan dari orang tua untuk melakukan hal-hal yang diperlukan bagi pendidikan anaknya. Kewenangan ini diberikan orang tua kepada sekolah karena orang tua adalah memiliki banyak keterbatasan (ekonomi dan pendidikan), sehingga untuk melaksanakan tugas pendidikan anaknya, para orang tua memerlukan resources lain di luar dirinya.

\section{Pengasuhan}

Di MAN Salatiga, pengarahan tentang pengasuhan disampaikan pada forum pertemuan orang tua dengan sekolah secara masal. Orang tua diminta untuk mendorong agar anaknya mengikuti kegiatan yang diselenggarakan di sekolah, seperti remidi, tambahan pelajaran, terutama bagi keluarga yang kurang mampu. Sekolah menyadari waktu anak lebih banyak di rumah dari pada di sekolah.

Menurut Jensen, orang tua dan guru perlu menciptakan lingkungan yang kondusif bagi anak. Lingkungan belajar yang

11 Hauberer, J., Social capital theory: Toward methodological foundation. : (Heidelberg: Springer Fachmedien, 2011), 42. 
diciptakan harus nyaman secara fisik, emosional, dan sosial bagi anak. ${ }^{12}$ Parenting merupakan upaya menyediakan suasana yang kondusif bagi pengembangan fisik dan emosi anak, membangun relasi emosi berdasarkan rasa cinta kasih, membimbing anak untuk memahami dunia dan budaya dan merancang lingkungan yang baik secara bersama-sama. Keberhasilan dan kegagalan parenting tergantung pada banyak hal menyangkut kesulitan-kesulitan yang dihadapi oleh anak dan tingkatan masalah yang ada di lingkungan sosial anak dan orang tua, yang tidak menyehatkan dan tidak memotivasi. Dengan demikian, penciptaan lingkungan belajar yang kondusif bagi anak di rumah menuntut adanya pengaturan lingkungan fisik dan penciptaan suasana yang mampu memberikan kenyamanan anak dalam belajar baik secara fisik, emosinal dan juga sosial. ${ }^{13}$

Dalam praktiknya, hal-hal yang perlu diperhatikan orang tua dan guru dalam mengatur lingkungan untuk belajar adalah : (a) suhu ruangan yang baik berkisar antara $20^{\circ}-25^{\circ} \mathrm{C}$; (b) tanaman, bunga, atau kembang; (c) akustik, dan mutu suara; d) poster, warna tembok; (e) bagus juga dipasang icon-icon affirmative di ruang belajar; (f) penerangan (alami atau listrik); g) binatang peliharaan, dan aquarium; (h) kursi tempat duduk; (i) tingkat kelembaban ruangan; j) pemandangan keluar; (k) penciuman, aroma positif di ruangan; (l) iringan musik.

Selain penataan lingkungan fisik, suasana kondusif juga terwujud melalui penciptaan lingkungan sosial yang baik dalam keluarga. Ada beberapa suasana yang diperlukan untuk mendukung suasana yang kondusif bagi pembelajaran anak di rumah antara lain: (a) mengembangkan hubungan positif dengan anak; (b) memberikan pelukan dan mencintai anak; (c) menciptakan lingkungan yang tenang; d) memberikan contoh yang baik; (e) membangun komunikasi positif dengan anak; (f) menemani anak belajar; (g) memberi kesempatan anak untuk mengembangkan kreativitas; (h) mengajarkan aturan,

${ }^{12}$ Eric Jensen, Guru Super \& Super Guru. (Terjemahan Benyamin Molan) (Jakarta Barat: Indeks, 2010), 4.

${ }^{13}$ Mc Dermott, D, Developing caring relationships among parents, children, schools, and communities (California: Sage Publications, Inc, 2008), 42, 93. 
ritual dan tanggung jawab; (i) menekankan hal-hal yang positif; dan (j) membuang hal-hal yang negatif. ${ }^{14}$

Perlu diketahui bahwa suasana psikologis di ruangan yang mempengaruhi belajar anak antara lain hubungan interpersonal di antara anggota keluarga, tingkat perkembangan individu, dan cara kontrol dari orang tua. ${ }^{15}$ Dalam hal penciptaan lingkungan sosial, beberapa hal yang sudah dapat diwujudkan pada keluarga siswa MAN Salatiga, antara lain : hubungan positif dengan anak, memberi kesempatan anak untuk mengembangkan kreativitas, mengajarkan aturan, ritual dan tanggung jawab, menekankan hal-hal yang positif, membuang hal-hal yang negatif.

Hasil riset yang dilakukan para ahli tahun 1998 dan tahun 2002 ditemukan bahwa, orang tua yang menyediakan lingkungan keluarga yang hangat, responsive, dan supportive mampu mendorong eksplorasi, menstimulasi keingintahuan, dan menyediakan materi bermain dan materi belajar mempercepat perkembangan intelektual anak-anak. Lingkungan keluarga yang mampu menyediakan stimuli tersebut melahirkan anak yang memiliki motivasi dan prestasi akademik lebih di sekolah. Relasi anak dengan orang tua sangat penting karena orang tua mempunyai pengaruh nomor satu terhadap perkembangan hidup anak sampai usia lima tahun, selanjutnya bergeser ke taman sebaya dan orang tua memberikan perhatian individual kepada anaknya yang tidak dapat dihasilkan oleh guru. Rekomendasi hasil penelitian ini, adalah perlunya program-program peningkatan pengetahuan orang tua tentang cara menyediakan pengalaman belajar yang kaya bagi anak-anak mereka. ${ }^{16}$

Dalam mengasuh anak, orang tua juga perlu diberi pemahaman yang baik dan benar mengenai makanan dan konsumsi nutrisi dan pengaturannya. Orang tua perlu diberi penjelasan yang memadai tentang pentingnya sarapan pagi, konsumsi nutrisi yang

${ }^{14}$ Mutia Ayu Krismanda, Bambang Ismanto, dan Ade Iriani, "Pengembangan Model Kemitraan Sekolah Dengan Orang Tua Melalui Media Sosial Dalam Peningkatan Mutu Berbasis Sekolah di Sekolah Menengah Swasta," Kelola: Jurnal Manajemen Pendidikan Vol. 4, no. 2 (Desember 2017): 146-160.

${ }^{15}$ Farida Hidayati, Dian Veronika Sakti Kaloeti, dan Karyono, "Peran Ayah dalam Pengasuhan Anak," Jur nal Psikologi Undip Vol. 9, no. No. 1 (April 2011): 1-10.

16 Asri Ramadani, Endang Sri Redjeki, dan Ahmad Mutadzakir, "Kemitraan Orangtua Dan Lembaga Pendidikan Dalam Pengasuhan Anak Usia Dini Berkebutuhan Khusus," Jurnal Pendidikan Nonformal Vol. 11, no. 1 (2016): 20-28. 
mencerdaskan otak dan menghindari makanan-makanan yang menyebabkan ngantuk atau menurunkan daya kerja otak. Selain itu orang tua juga perlu diberi pengetahuan tentang variasi pengaturan menu makanan setiap harinya, sehingga anak tidak malas makan di rumah.

Menurut Novie, sarapan pagi merupakan upaya untuk memenuhi kebutuhan tubuh akan nutrisi yang sangat dibutuhkan otak saat akan bekerja. Penelitian Sendai, membuktikan bahwa sarapan pagi menunjang perkembangan otak, khususnya bagianbagian otak yang penting untuk menunjang aktivitas belajar; penelitian Mahoney tahun 2004, menyimpulkan bahwa makanan yang dikonsumsi sebelum ke sekolah adalah jenis makanan yang mengandung karbohidrat berserat tinggi atau karbohidrat kompleks. Penelitian Taki menunjukkan bahwa jenis sarapan yang paling baik untuk sarapan anak sebelum berangkat ke sekolah adalah nasi karena diketahui bahwa anak-anak yang makan nasi setiap pagi sebelum ke sekolah memiliki hasil tes yang lebih baik. Bagian-bagian otak yang penting untuk tugas kognitif seperti prefrontal cortex, orbitofrontal cortex, dan cingulate, mengalami penebalan materi abu-abu dan materi putih. Dalam menyediakan menu sehari-hari, orang tua perlu memahami tentang jenis makanan yang mampu meningkatkan daya kerja otak, agar kekuatan kerja otak anak dapat maksimal. Orang tua juga perlu memilih bahan makanan yang organik. Penelitian terbaru menunjukkan bahwa adanya hubungan antara pestisida dalam pertanian dengan melemahnya daya ingat, munculnya depresi, perubahan suasana hati atau agresivias. ${ }^{17}$

Menurut Febry \& Marendra, ada dua belas jenis makanan yang dijuluki brain food, yang sangat baik untuk anak usia sekolah karena mampu merangsang pertumbuhan sel-sel otak, memperbaiki fungsi otak, meningkatkan daya ingat, dan konsentrasi berpikir. Keduabelas jenis makanan tersebut adalah ikan dan kerang-kerangan, telur, daging sapi, daging ayam, gandum murni, Oat/oatmeal, beras merah, kelompok berry, kacang-kacangan, buah dan sayuran berwarna, susu dan yogurt, keju. ${ }^{18}$

17 Lorraine Paretta, Makanan untuk Otak (Terjemahan Shinta Teviningrum) (Jakarta: Erlangga, 2004), 1, 2, 24.

18 Olsen dan Fuller, M.O., Home and school relation, 106. 
Selain diberi informasi tentang makanan-makanan yang mampu membantu meningkatkan kinerja otak anak, orang tua juga perlu diberi informasi tentang jenis makanan yang menurunkan daya kerja otak anak. Menurut Unoviana beberapa jenis makanan yang dapat menurunkan kinerja otak anak adalah omelet putih telur, agave, tuna, popcorn microwave, biskuit dan keripik, makanan berkadar gula tinggi, alkohol, junk food, makanan yang digoreng, makanan yang sangat asin, pemanis buatan, nikotin. Pendapat lain, dikemukakan oleh Paretta, pengaturan konsumsi nutrisi bagi anak agar mampu menopang aktivitas otaknya. Jenis-jenis menu makanan yang disarankan untuk dikonsumsi anak usia sekolah adalah mencakup menu untuk keningkatkan IQ, menu untuk penguat otak, makanan untuk membantu menghalau dan mengatasi stress anak. ${ }^{19}$

Anak terkadang juga merasakan kantuk ketika mengikuti kegiatan pembelajaran di sekolah yang diakibatkan oleh berbagai faktor, misalnya faktor fisik karena kecapaian, pembelajaran yang tidak menarik, suasana ruangan yang tidak kondusif, atau karena faktor makanan. Menurut Widjaya, beberapa makanan yang disarankan agar tidak dikonsumsi anak ketika akan belajar agar tidak cepat mengantuk adalah pisang, teh hijau, susu, buah Ceri, sereal, kacang Almond, kedelai.

Berbagai jenis makanan tersebut tentunya tidak semuanya dapat dijumpai orang tua siswa MAN Negeri Salatiga. Untuk mengatasi hal tersebut, orang tua dapat memanfaat potensi sumber makanan yang ada disekitarnya guna memenuhi kebutuhan gizi anaknya, misalnya kelompok sayuran seperti sayuran hijau, daun singkong, daun sawi, brokoli, bayam, jagung, kangkung, brokoli, kubis, kembang kol, cabe, jamur, wortel, buncis, labu, mentimun, dsb; kelompok kacang-kacangan misalnya wijen, kedelai, kacang tanah, kacang hijau, biji bunga matahari, kacang mete, dsb; kelompok buah-buahan seperti pisang, papaya, jeruk, tomat, apel, alpukat, mangga, kelengkeng, duku, rambutan, manggis, durian; kelompok lauk pauk misalnya tahu, tempe, ikan air tawar, hati sapi, daging sapi, telur, udang, lele, gurami, nila, belut, daging ayam, bebek;

19 Kompas Cyber Media, "5 Makanan yang Menurunkan Kinerja Otak," KOMPAS.com, 19 April 2014, https://health.kompas.com/

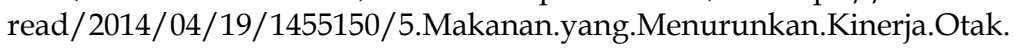


kelompok sumber energi misalnya singkong, beras, bekatul, jagung, umbi-umbian, kentang, dedak; kelompok lain seperti susu sapi dan susu kedelai.

\section{Pembelajaran di Rumah}

Sekolah-sekolah di Salatiga selama ini belum menyediakan informasi kepada orang tua tentang kebutuhan belajar anak yang harus dikuasai di sekolah. Informasi tentang kebutuhan belajar anak, disampaikan sekolah dalam bentuk buku pedoman akademik dan tata tertib sekolah yang dibagikan kepada orang tua pada awal tahun ajaran. Sekolah juga belum memiliki science corner bagi para orang tua untuk menambah pengetahuan dan skill mereka dalam pendampingan anak.

Menurut Scott, para guru berpandangan bahwa orang tua perlu meningkatkan pengetahuan dan skill mereka tentang berbagai mata pelajaran sehingga dapat mendampingi anaknya belajar di rumah. Orang tua juga perlu adaptif dalam penguasaan skill komputer dan berbagai teknologi informasi dan komunikasi saat ini. Dengan menyediakan forum dan sudut science tersebut maka orang tua memiliki kesempatan untuk meningkatkan pengetahuan dan skill tersebut. ${ }^{20}$

Namun, keadaan orang tua yang sebagian besar berasal dari golongan ekonomi menengah ke bawah (MAN Salatiga, orang tua bekerja di sektor swasta $41,76 \%$, petani $16,13 \%$ ) dan berpendidikan rendah (orang tua MAN Salatiga lulusan SD 40,6\%, SLTP 33,8\%), kurang memungkinkan tercapainya harapan tersebut. Satu terobosan yang dikembangkan di MAN Salatiga adalah membentuk kelompok-kelompok belajar bagi peserta didik kelas XII. Kelompok belajar ini untuk mengatasi minimnya perhatian orang tua dalam pendampingan belajar anak di rumah karena minimnya pengetahuan orang tua tentang belajar ataupun karena kesibukan orang tua bekerja mencari nafkah.

Selama ini, para orang tua menghabiskan waktunya untuk bekerja pada siang hari, sementara pada malam hari mereka gunakan untuk beristirahat atau bahkan menyelesaikan pekerjaan yang

${ }^{20}$ Olsen dan Fuller, M.O., Home and school relation, 106. 
terntunda pada siang hari. Mereka tidak mengetahui bagaimana cara mendampingi belajar anak dan bagaimana mengarahkan masa depan anak mereka. Mereka tidak berbuat bukan berarti mereka tidak peduli, namun karena ketidaktahuannya akan seluk beluk pendidikan anaknya.

Orang tua harus senantiasa diberi pemahaman tentang pentingnya mengatur waktu bagi anaknya di rumah. Menurut Larson \& Verma, waktu yang digunakan anak di luar sekolah sejak bangun tidur adalah $70 \%$, sedangkan waktu yang digunakan untuk kegiatan belajar di sekolah 30\%. Orang tua perlu membantu anak untuk memaksimalkan waktu belajar di luar sekolah, termasuk mengelola waktu anak setelah pulang dari sekolah dan pembentukan berbagai komunitas yang edukatif. ${ }^{21}$

\section{Sukarelawan}

Sekolah-sekolah di Salatiga belum memiliki program mengidentifikasi potensi relawan yang ada di sekitarnya. Kegiatan volunteering selama ini dilaksanakan secara insidentil seperti program tahfidz, pramuka, PMR, dan lainnya. Identifikasi dilakukan terhadap orang tua, guru dan unsur lain yang terkait dalam hubungannya dengan seleksi calon anggota komite sekolah.

Di kota Salatiga banyak sekali organisasi kemasyarakatan yang dapat diajak bermitra menjadi relawan bagi sekolah. Lembagalembaga tersebut bergerak dalam sepuluh bidang kegiatan, yaitu kesehatan, hankam sosial (7 lembaga), sosial keagamaan (16 lembaga), seni budaya (7 lembaga), sosial kemasyarakatan (8 lembaga), bisnis ekonomi (5 lembaga), konstruksi teknik sipil (3 lembaga), pendidikan keluarga kewanitaan (2 lembaga), pembinaan generasi muda ( 7 lembaga), pembinaan profesi (4 lembaga).

Jika melihat dari kegiatan relawan di sekolah yang selama ini sudah dilaksanakan, ada lima tema besar kegiatan relawan yang dilaksanakan di sekolah, yaitu tema akademik, non-akademik, kesehatan, hukum dan kewirausahaan; sementara itu bidang-bidang lain seperti kesenian, olah raga, hankam, sosial kemasyarakatan, hobbi belum dapat dikembangkan oleh relawan di sekolah karena pihak

${ }^{21}$ David Hopkins, Every school a great school: Realizing the potential of system leadership (Maidenhead: Open University Press, 2007), 117. 
sekolah sudah terlalu banyak disibukkan dengan kegiatan 'tupoksi' persekolahan, yaitu kegiatan pembelajaran formal. Sementara pihak relawan kurang memahami bahwa sekolah juga dapat dijadikan sebagai objek realisasi program kerjanya. Realisasi program kerja institusi-institusi sosial tersebut selama ini baru terkonsentrasi pada internal member.

Kalau dicermati di sekitar sekolah, sebenarnya banyak sekali sumber daya (resource) atau modal (capital) yang dapat dimanfaatkan untuk memajukan sekolah. Paling tidak ada tiga capital yang harus dimiliki sekolah, yaitu intellectual capital, social capital, organizational capital agar dapat mewujudkan sekolah yang bermutu. Dalam perspektif social capital, antara sekolah dan beberapa lembaga lain belum mengoptimalkan koneksi mutualistik. Koneksi ini yang terkadang saling tidak dipahami oleh sekolah dan lembaga-lembaga sosial kemasyarakatan, yang pada akhirnya mereka saling jalan sendiri dalam mewujudkan visinya. Sebagian dari mereka sudah mengetahui hal tersebut namun karena faktor tertentu jalinan kemitraan tersebut tidak dapat diwujudkan. ${ }^{22}$

Sejalan dengan keadaan tersebut, Nelson menyatakan bahwa salah satu sumber belajar yang dapat dimanfaatkan dalam pembelajaran adalah masyarakat lokal karena masyarakat kaya akan materi ajar, untuk memperkuat kerjasama sekolah dan masyarakat, memupuk rasa bangga pelajar, menjadikan materi pelajaran lebih relevan dengan kebutuhan anak didik, memperkenalkan model pembelajaran yang variatif. Nelson, menyebutkan bahwa hal-hal yang dapat dijadikan sebagai sumber belajar dalam masyarakat adalah sumber daya budaya, orang yang memiliki pekerjaan khusus dan pensiunan, kelompok masyarakat, asosiasi, dan organisasi sosial, surat kabar local. ${ }^{23}$

Jika sekolah dapat menggandeng volunteer ke sekolah, banyak hal yang dapat dikerjakan untuk membantu sekolah. Beberapa

${ }^{22}$ Annisa Nurul Utami, Neti Hernawati, dan Alfiasari, "Pengasuhan Orang Tua Yang Seimbang Sebagai Kunci Penting Pembentukan Karakter Remaja," Jurnal Pendidikan Karakter Vol. VI, no. No. 1 (6 April 201M): 1-16.

${ }^{23}$ Aria Luqita Agus Susanti dan Pramesti P. Paramita, "Perspektif Guru terhadap Kemitraan antara Sekolah, Guru dan Masyarakat di SDN Inklusif di Surabaya," urnal Psikologi Industri dan Organisasi Vol. 2, no. 2 (2013): 158-168. 
kegiatan yang dapat dilakukan relawan adalah membantu di kantor, membantu kegiatan sekolah, menjadi guru pembimbing siswa bagi yang membutuhkannya di luar jam pelajaran, membantu dalam penerbitan newsletter, menjadi salah satu nara sumber bagi para guru, bertindak sebagai penghubung bagi keluarga yang tidak dapat berkomunikasi dengan baik, membantu kelompok belajar siswa, mengumpulkan sumber materi ajar, menjadi penasehat para siswa, menyediakan bantuan bagi pengerjaan tugas pekerjaan rumah bagi para siswa. ${ }^{24}$

Pelibatan orang tua dalam berbagai kegiatan sekolah dilaksanakan melalui perwakilan komite sekolah, yang terlibat mulai dari perencanaan, pelaksanaan dan pengawasan. Sekolah juga memiliki data lengkap orang tua siswa yang disimpan di ruang Bimbingan Konseling.

Menurut Olsen dan Fuller, sekarang telah terjadi perubahan paradigma pengelolaan pendidikan dari agency orientation approach (pendekatan berorientasi pada lembaga, sekolah) ke family centered intervention (intervensi yang berpusat pada keluaga). Agency orientation approach berpandangan bahwa mewujudkan sekolah yang bermutu dilakukan dengan memperkuat manajemen internal sekolah, sementara paradigma family centered intervention berpandangan bahwa sekolah yang bermutu dapat diwujudkan dengan mengoptimalkan keterlibatan keluarga dalam pengelolaan pendidikan anak di sekolah. ${ }^{25}$

Perubahan orientasi ini didasarkan pada realitas bahwa keluarga adalah institusi yang pertama dan utama dalam pendidikan anak. Nilai-nilai yang diwariskan dalam pendidikan keluarga sangat dominan dalam membentuk performa anak. Sementara itu, pendidikan di sekolah adalah pendidikan lanjutan yang berfungsi melengkapi kekurangan dalam pendidikan dalam keluarga. ${ }^{26}$

\footnotetext{
${ }^{24}$ Aria Luqita Agus Susanti dan Pramesti P. Paramita.

${ }^{25}$ Istina rakhmawati, "Peran Keluarga Dalam Pengasuhan Anak," KONSELING RELIGI: Jurnal Bimbingan Konseling Islam Vol. 6, no. 1 (Juni 2015): 1-18.

26 Saiful Hadi, "Pola Pengasuhan Islami Dalam Pendidikan Keluarga (Penguatan Peran Keluarga Jamaah Masjid Baitul Abror Teja Timur)," Jurnal Tadris Vol. 12, no. 1 (Juni 2017): 117-133.
} 


\section{Pengambilan Keputusan}

Kepala sekolah di Salatiga sebelum mengambil keputusan meminta pertimbangan kepada guru dan karyawan dan selalu mengapresiasi dan menindaklanjuti usulan dari bawah yang bermaksud ingin memajukan sekolah. Kepala sekolah meminta kepada guru dan karyawan usulan yang rinci sampai pada tahap pelaksanaannya. Usulan guru atau karyawan tersebut kemudian dibahas di forum rapat sekolah. Kepala sekolah sangat terbuka dalam kepemimpinan, terbuka menerima saran dan kritik, suka berdiskusi di manapun.

Dalam istilah manajemen, kepemimpinan partisipatif juga dikenal dengan nama kepemimpinan terbuka, bebas atau nondirective. Kepala Sekolah yang menganut pendekatan ini, sedikit memegang kendali dalam proses pengambilan keputusan, memaparkan informasi mengenai suatu permasalahan dan memberikan kesempatan kepada guru dan karyawan untuk mengembangkan strategi dan memecahkannya. Secara umum keuntungan pengambilan keputusan partisipatif adalah meningkatkan kualitas keputusan karena pengambilan keputusan melibatkan orang banyak. Pengambilan keputusan partisipatif juga dapat meningkatkan komitmen dan rasa tanggung-jawab bersama terhadap keputusan yang telah diambil. ${ }^{27}$

Untuk pengembangan sekolah, mereka belum memiliki dynamic group permanen, yang ada adalah tim kerja insidentil. Pengembangan kelembagaan diserahkan kepada unit terkait, misalnya waka kurikulum, waka sarpras, waka kesiswaan atau bakat minat. Tim kerja yang dibentuk secara insidentil misalnya pada kegiatan UN, PHBI, PPDB.

Istilah lain yang serupa untuk menyebut semacam dynamic group adalah tim kerja (team work), yaitu sekelompok individu yang bekerja dan mampu menghasilkan kinerja yang lebih tinggi dari pada kerja individual. Dalam praktiknya, ada berberapa jenis tim kerja, yaitu: (a) tim penyelesaian masalah (problem solving team); (b) tim kerja yang mengelola diri sendiri (self-managed-work-team); (c) tim lintas fungsional (cross-functional-team); (d) tim virtual (virtual team).

27 Yunida Cahya Kinanti, “Kemitraan Sekolah Dalam Meningkatkan Mutu Pendidikan di SMA Negeri 2 Yogyakarta," Jurnal Kebijakan Pendidikan 5, no. 5 (2016): 478-490. 


\section{Bekerjasama dengan Masyarakat}

Sekolah-sekolah di Salatiga memiliki cara yang sama dalam menginformasikan kegiatan layanan masyarakat kepada orang tua atau peserta didik, yaitu ditempel di papan pengumuman yang terletak di depan ruang BK misalnya informasi dari berbagai lembaga kursus semacam PRIMAGAMA, GAMA EXACTA, GANESA dan kursuskursus bahasa Inggris., sosialisasi per kelas dengan menggunakan jam pelajaran BK misalnya sosialisasi penerimaan mahasiswa baru, surat edaran, melalui, dan website informasi tentang sister school dan tata cara pendaftaran calon peserta.

Menurut Garbarino, sekolah dan orang tua harus mengetahui berbagai layanan yang ada dalam masyarakat. Tujuannya adalah untuk membantu orang tua dan anaknya mengatasi masalahnya dan untuk menghindari penyimpangan yang lebih lanjut. Berbagai layanan masyarakat ini berbeda antar komunitas yang satu dengan yang lainnya. ${ }^{28}$

Sekolah melakukan kegiatan bersama dengan institusi-institusi di kota Salatiga seperti donor darah dan kegiatan ekstrakurikuler, periksa gigi gratis, penyuluhan narkoba dan kesadaran berlalu lintas, tes bakat. Kegiatan sekolah bersama berbagai elemen masyarakat, misalnya festival budaya, pentas seni, jalan santai jeda semester, hari raya Idul Fitri, hari Raya Qurban, PHBI, wisuda, bantuan tanggap bencana alam, bazaar, dan bhakti sosial pada saat kemah bhakti. Sementara itu, kegiatan sekolah bersama alumni dalam bentuk reuni, bantuan beasiswa, bantuan peralatan pembelajaran di sekolah, motivasi dan fasilitasi penerimaan siwa baru.

Jika dikaitkan dengan teori pertukaran, maka dalam pertukaran harus ada apa yand disebut dengan persesuaian kebutuhan ganda (double coincidence of wants), yaitu keduanya membutuhkan barang yang dimiliki pihak lain, sehingga mereka bersedia menyerahkan apa yang dimiliki itu kepada pihak lain melalui pertukaran. ${ }^{29}$ Dari enam puluh organisasi lembaga sosial kemasyarakatan yang ada di

${ }^{28}$ Berns, R.M, Child, family, school, and community (Colonia Polanco: Thomson Learning, 2004), 428.

${ }_{29}^{2}$ Coleman, J.S, Dasar-dasar teori sosial (Terjemahan Imam Muttaqien, Derta Sri Widowatie, SiwiPurwandari), 121. 
kota Salatiga, baru lima organisasi yang mejalin kerja sama kemitraan dengan sekolah SLTA kota Salatiga, yaitu PMI, MUI, KONI, Pramuka STAIN, dan Paguyuban Asmoro Budaya. Kelima lembaga sosial kemasyarakatan tersebut memiliki sesuatu yang dapat dipertukarkan dengan sekolah yang bersifat mutualistik.

Upaya sekolah menyampaikan informasi kepada masyarakat dan menginformasikan kegiatan masyarakat kepada peserta didik dan orang tua merupakan bentuk kesadaran akan arti penting informasi. Potensi informasi sebagai salah satu bentuk social capital sangat penting bagi individu atau kelompok individu. Sekolah adalah pihak yang dianggap valid dalam menyediakan informasi, baik informasi dari sekolah, masyarakat, orang tua maupun lainnya.

Sekolah sebagai bagian dari organisasi sosial berkepentingan untuk melakukan kegiatan integral dengan organisasi sosial lainnya guna menyelesaikan masalah, terutama berkaitan dengan human resources. Organisasi sosial menyediakan human resources yang melimpah yang dapat dimanfaatkan sekolah untuk menutup kekurangannya. Organisasi sosial juga menyediakan material capital, yang dapat dimanfaatkan sekolah untuk memperkaya kegiatan pembelajaran. Dalam hal ini yang terpenting adalah memper-temukan kesamaan gagasan, ide dan interest antara sekolah dan organisasi sosial yang ada. ${ }^{30}$

\section{F. Faktor Pendukung dan Penghambat}

Kemitraan antara sekolah, orang tua, dan lembaga sosial kemasyarakatan di kota Salatiga dapat berjalan dengan baik didukung oleh berbagai faktor, baik dari sekolah, orang tua ataupun masyarakat. Faktor dari orang tua adalah munculnya kesadaran orang tua untuk datang ke sekolah dan proaktif berkonsultasi terkait dengan pendidikan anaknya di sekolah, Faktor dari siswa berupa munculnya kesadaran tinggi akan fungsi BK sebagai partner yang membantu mereka dalam meraih kesuksesan. Faktor dari sekolah berupa: (a) semangat profesionalisme para guru, karyawan dalam menjalankan tugas dan berinovasi; dan (b) petugas BK yang proaktif mengatasi

30 Syamsul Arifin, "Kemitraan Sekolah-Masyarakat Sebagai Upaya Peningkatan Mutu Pendidikan Di Sampang Jawa Timur," JURNAL HUMANITY Vol. 8, no. 1. (September 2012): 203-2019. 
masalah anak. Faktor dari elemen masyarakat berupa: (a) sikap koperatif berbagai elemen masyarakat untuk mendukung program kegiatan sekolah; dan (b) sikap kepedulian elemen masyarakat terhadap pendidikan anak di sekolah.

Menurut Petersen, untuk mengoptimalkan pengalaman dan partisipasi dalam kegiatan pendidikan, semua orang harus terlibat dalam kegiatan tersebut, baik sekolah, orang atau masyarakat. Petersen menyebutkan bahwa ..school, families and communities are blossoming together to support children's growth, knowledge, and development...some responsibilities are shared, and some are separate... a firm "root system" must support the entire relationship in order for a partnership to 'blossom' (sekolah, keluarga, dan masyarakat 'mekar' bersama mendorong pertumbuhan, pengetahuan, dan perkembangan anak....beberapa hal menjadi tanggung bersama... beberapa hal menjadi tanggung jawab masing-masing...sebuah usaha 'sistem akar' harus mendukung segala usaha kemitraan agar dapat berkembang. ${ }^{31}$ Dengan demikian, keberhasilan kemitraan akan terwujud manakal didukung oleh semua pihak, yaitu sekolah, keluarga dan masyarakat.

Orang tua merupakan salah satu sosial kapital bagi sekolah yang sangat berperan dalam pencapaian tujuan pendidikan di sekolah. Antar sekolah dan orang tua ada kewajiban dan ekspektasi yang mampu menggerakkan kedua elemen tersebut untuk melaksanakan tugas pendidikan. Sekolah memiliki kewajiban untuk melaksanakan tugas mendidik bagi anak-anak yang telah diserahkan orang tua kepada institusi tersebut, sementara orang tua memiliki ekspektasi yang terhadap sekolah atas keberhasilan anaknya dalam pendidikan di sekolah. ${ }^{32}$

Beberapa faktor pengambat kemitraan pendidikan di kota Salatiga, muncul dari orang tua, siswa, dan sekolah. Faktor dari orang tua berupa, tidak bersedia datang ke sekolah, pasrah sepenuhnya kepada sekolah tentang urusan pendidikan anaknya, perhatian orang tua terhadap pendidikan anaknya tergolong rendah, status ekonomi

${ }^{31}$ Cox-Petersen, A, Educational partnership, connecting schools, families, and the community (California: Sage Publications, Inc, 2011), 21.

32 Taufik Rihatno, Yufiarti, dan Sri Nuraini, "Pengembangan Model Kemitraan Sekolah Dan Orangtua Pada Pendidikan Anak Usia Dini," JURNAL PENDIDIKAN USIA DINI 11, no. 1 (April 2017): 117-129. 
orang tua tergolong lemah, tingkat pendidikan orang tua rendah, orang tua meremehkan sekolah. Faktor dari siswa adalah siswa tidak memberikan undangan dari sekolah kepada orang tuanya. Faktor dari sekolah adalah pihak sekolah lebih terkonsentrasi pada sukses UN, sekolah juga sedang berkonsentrasi dalam pembenahan manajemen internal.

Sementara itu, di sisi lain salah satu bentuk modal sosial lain adalah relasi wewenang, yaitu kewenangan yang diberikan oleh sesorang kepada orang lain sebagai relasinya untuk melakukan tindakan tertentu. Namun jika pemberian kewenangan berlebihan, sampai menimbulkan pasrah juga menimbulkan dampak yang kurang baik. Sikap pasrah dalam pemberian wewenang ini cenderung terdapat pada keluarga dengan kondisi sosial, ekonomi, dan pendidikan rendah. Mereka merasa tidak mampu, kurang percaya diri (lack of efficacy, lack of confidence).

\section{Dampak Kemitraan Pendidikan}

Kemitraan yang dikembangkan sekolah mengacu pada karakteristik khusus sekolah, yang berdampak pada performa lulusannya sesuai dengan karakteristik sekolah. MAN memiliki kekhasan dalam bidang moral dan menjalin kemitraan dengan lembaga-lembaga yang dianggap mampu mensupport pembentukan moral peserta didiknya. Dampaknya terhadap lulusannya adalah mereka memiliki keunggulan dalam bidang keagamaan (misalnya hafal al Qur'an 30 juz) dan para lulusananya lebih dominan melanjutkan kuliah pada perguruan tinggi agama (misalnya ke IAIN).

Dampak kemitraan pendidikan terhadap orang tua adalah mereka lebih mengetahui akan tugas dan perannya dalam pendidikan anak, memahami bahwa di sekolah anak-anak dididik oleh para guru, memahami tentang program-program sekolah, keuangan sekolah dan anggaran belanja sekolah, di rumah, mereka harus senantiasa ikut mengawasi kegiatan anaknya. Menurut Epstein (2009,p.18), kemitraan pendidikan sangat bermanfaat bagi orang tua peserta didik, komunikasi (communicating) membuat orang tua semakin memahami program dan kebijakan sekolah, menyadari akan perlunya memonitor kegiatan belajar anak, mampu merespond secara positif atas berbagai 
permasalahan anaknya, mampu berinteraksi dengan para guru atau pihak sekolah terkait dengan pendidikan anaknya. ${ }^{33}$

\section{G. Simpulan}

MAN Salatiga memandang perlunya memanfaatkan berbagai sumber daya dalam masyarakat untuk mengatasi berbagai keterbatasan penyelenggaraan pendidikan dalam rangka memenuhi tuntutan kebutuhan masyarakat. Pengembangan kemitraan pendidikan di MAN Salatiga didukung oleh modal sosial yang dipengaruhi oleh jenis sekolah, ini-siatif dan interest, keadaan orang tua, kebijakan sekolah dan partisipasi politik. Kemitraan pendidikan di MAN Salatiga mempengaruhi mutu sekolah, lulusan, dan orang tua.

MAN Salatiga sebaiknya mengingkatkan upaya mengidentifikasi resources yang ada di sekitar sekolah, untuk selanjutnya dimanfaat dalam rangka memperkaya pembelajaran. memperkaya pembelajaran. MAN Salatiga perlu mendesain pengembangan kemitraan pendidikan secara sungguh-sungguh dalam rangka memperkuat eksistensi sekolah[.]

\section{REFERENSI}

Abdullah Idi. Sosiologi Pendidikan: Individu, Masyarakat, dan Pendidikan. Jakarta: Raja Grafindo, 2013.

Annisa Nurul Utami, Neti Hernawati, dan Alfiasari. "Pengasuhan Orang Tua Yang Seimbang Sebagai Kunci Penting Pembentukan Karakter Remaja." Jurnal Pendidikan Karakter Vol. VI, no. No. 1 (6 April 201M): 1-16.

Aria Luqita Agus Susanti, dan Pramesti P. Paramita. "Perspektif Guru terhadap Kemitraan antara Sekolah, Guru dan Masyarakat di SDN Inklusif di Surabaya." urnal Psikologi Industri dan Organisasi Vol. 2, no. 2 (2013): 158-168.

Asri Ramadani, Endang Sri Redjeki, dan Ahmad Mutadzakir. “Kemitraan Orangtua Dan Lembaga Pendidikan Dalam

${ }^{33}$ Epstein, J.L, School, family and community partnership (California: Crown Press, 2009), 18. 
Pengasuhan Anak Usia Dini Berkebutuhan Khusus." Jurnal Pendidikan Nonformal Vol. 11, no. 1 (2016): 20-28.

Berns, R.M. Child, family, school, and community. Colonia Polanco: Thomson Learning, 2004.

Coleman, J.S. Dasar-dasar teori sosial (Terjemahan Imam Muttaqien, Derta Sri Widowatie, SiwiPurwandari). Bandung: Nusa Media, 2009.

Cox-Petersen, A. Educational partnership, connecting schools, families, and the community. California: Sage Publications, Inc, 2011.

Creswell, J.W. Qualitative inquiry \& research design: Choosing among five approaches. California: Sage Publications, Inc, 2007.

David Hopkins. Every school a great school: Realizing the potential of system leadership. Maidenhead: Open University Press, 2007.

Depdiknas. Manajemen peningkatan mutu berbasis sekolah: Konsep dan pelaksanaan. Jakarta: Depdiknas Direktorat SLP, 2002.

Epstein, J.L. School, family and community partnership. California: Crown Press, 2009.

Eric Jensen. Guru Super \& Super Guru. (Terjemahan Benyamin Molan). Jakarta Barat: Indeks, 2010.

Farida Hidayati, Dian Veronika Sakti Kaloeti, dan Karyono. "Peran Ayah dalam Pengasuhan Anak." Jur nal Psikologi Undip Vol. 9, no. No. 1 (April 2011): 1-10.

Fasli Jalal, dan Dedi Supriyadi (Ed). Reformasi Pendidikan Dalam Konteks Otonomi Daerah. Yogyakarta: Adicita, 2001.

Hauberer, J. Social capital theory: Toward methodological foundation. : Heidelberg: Springer Fachmedien, 2011.

Istina rakhmawati. "Peran Keluarga Dalam Pengasuhan Anak." KONSELING RELIGI: Jurnal Bimbingan Konseling Islam Vol. 6, no. 1 (Juni 2015): 1-18.

Kusumastuti, Ayu. "Modal Sosial dan Mekanisme Adaptasi Masyarakat Pedesaan dalam Pengelolaan dan Pembangunan Insfrastruktur." MASYARAKAT: Jurnal Sosiologi 20, no. 1 (2015): 81-97.

Lorraine Paretta. Makanan untuk Otak (Terjemahan Shinta Teviningrum). Jakarta: Erlangga, 2004. 
Mc Dermott, D. Developing caring relationships among parents, children, schools, and communities. California: Sage Publications, Inc, 2008.

Media, Kompas Cyber. "5 Makanan yang Menurunkan Kinerja Otak." KOMPAS.com, 19 April 2014. https://health.kompas.com/ $\mathrm{read} / 2014 / 04 / 19 / 1455150 / 5 . M a k a n a n . y a n g . M e n u r u n k a n$. Kinerja.Otak.

Mutia Ayu Krismanda, Bambang Ismanto, dan Ade Iriani. "Pengembangan Model Kemitraan Sekolah Dengan Orang Tua Melalui Media Sosial Dalam Peningkatan Mutu Berbasis Sekolah di Sekolah Menengah Swasta." Kelola: Jurnal Manajemen Pendidikan Vol. 4, no. 2 (Desember 2017): 146-160.

Olsen, dan Fuller, M.O. Home and school relation. New Jersey: Pearson, 2012.

Saiful Hadi. “Pola Pengasuhan Islami Dalam Pendidikan Keluarga (Penguatan Peran Keluarga Jamaah Masjid Baitul Abror Teja Timur)." Jurnal Tadris Vol. 12, no. 1 (Juni 2017): 117-133.

Syamsul Arifin. "Kemitraan Sekolah-Masyarakat Sebagai Upaya Peningkatan Mutu Pendidikan Di Sampang Jawa Timur." JURNAL HUMANITY Vol. 8, no. 1. (September 2012): 203-219.

Taufik Rihatno, Yufiarti, dan Sri Nuraini. "Pengembangan Model Kemitraan Sekolah Dan Orangtua Pada Pendidikan Anak Usia Dini." JURNAL PENDIDIKAN USIA DINI 11, no. 1 (April 2017): 117-129.

Tilaar, H.A.R. Paradigma baru pendidikan nasional. Jakarta: Rineka Cipta, 2004.

Yunida Cahya Kinanti. "Kemitraan Sekolah Dalam Meningkatkan Mutu Pendidikan Di Sma Negeri 2 Yogyakarta." Jurnal Kebijakan Pendidikan 5, no. 5 (2016): 478-490.

Zainuddin Maliki. Sosiologi Pendidikan. Yogyakarta: Gadjah Mada University Press, 2010. 
